\title{
HOW TO RECOGNIZE REVENUES FROM GROSS WRITTEN PREMIUM: SOME EVIDENCE FROM INSURANCE COMPANIES OPERATING IN CEE MARKETS
}

\author{
Jiřina BOKŠOVÁ - Jiř́ STROUHAL ${ }^{5}$ \\ Škoda Auto University Mladá Boleslav
}

\begin{abstract}
The research objective of this paper is to compare the current approaches in reporting of gross written premium in selected Central and Eastern European countries. Under current Czech regulations, the gross written premium in majority of Czech insurance companies is charged under the payment method set in the contract (i.e. annually, quarterly, monthly, etc.), however revenues from gross written premium for the accounting period are always shown in the proper amount. Our research confirmed that presented information about gross written premium in various jurisdictions is based on different methodologies and proved that for the comparability of data and for their information capability there is crucial to develop a precise definition of gross written premium; only in such case there would be possible to ensure the credibility of statistical data. Using these incomparable data may lead in many cases to misleading conclusions when evaluating the level of insurance in various countries and regions.
\end{abstract}

\section{KEY WORDS}

insurance, gross written premium, life insurance, non-life insurance

\section{INTRODUCTION}

All changes in the society are directly reflected in the insurance activity. New risks appear and therefore new insurance products appear as well. Insurance activities are divided into non-life insurance, life insurance, and in recent years increase also a share of life unit linked insurance. Yield in the form of gross written premium arises to the insurance company under insurance contracts and then must be adjusted about so called unearned premiums.

\section{THEORETICAL BACKGROUND OF APPROACHED AREA}

The insurance system is an exceedingly important branch of every free market economy and its function is non-fungible in a modern state with a free market economy. All changes in the society directly reflect into the insurance industry as well. Trade literature documents that new risks appear

\footnotetext{
${ }^{5}$ Correspondence address:

Jiřina Bokšová, doc. Ing. Ph.D.; Škoda Auto University, Department of Financial and Managerial Accounting, Na Karmeli, 29301 Mladá Boleslav, email: boksova@is.savs.cz

Jiří Strouhal, doc. Ing. Ph.D.; Škoda Auto University, Department of Financial and Managerial Accounting, Na Karmeli, 29301 Mladá Boleslav, email: ystrouhal@is.savs.cz
} 
hence new insurance products appear as well (see Belás et al., 2012; Bonaci et al., 2010; Smrčka et al., 2013).

In conditions of the Czech Republic under the term insurance system is understood a branch of economics that deals with insurance, security and intermediary activity in area of commercial insurance and connected activities. For the summary of risks covered by an appropriate insurance as they are undertaken by the insurance company is used a term insured risk. The insured risk is always determined by the insurance law scope, the insurance time validity is mentioned - period of coverage and local definition. The activity of insurance companies is at the present time controlled by laws, public notices, stipulations and by-laws of insurance companies that represent so-called insurance terms and conditions, extension of the contribution (Bokšová, 2010).

Premium represents a pre-paid hire for assignment of negative financial implications of accidentality from the enterprise and other economic entities to the insurance company. The insurance payment represents a compensation for damage by the insurance company on the insured property, compensations from the casualty, life, retirement income insurances or the insurance payment with the liability insurance.

Basic classification of premium is for the non-life insurance - above all represented by property insurance, liability insurance, casualty insurance and private health insurance and for life insurance - above all represented by insurance of persons. Among basic differences in accounting of insurance companies and business entities belong:

- different asset classification for financial placement and other property of the insurance company;

- creating technical reserves;

- valuating by the fair value at financial placement and technical reserves to the date of final accounts or to another moment when the final accounts is made;

- separated monitoring of life and non-life insurance;

- costs and profits are divided in accordance with activities on a servicing account for the life insurance and a non-servicing account;

- accounting about reinsurance; and

- insurance company solvency declaring.

Premium represents a price of insurance. Insurance serves in the insurance company for coverage of insurance risk, acquisition costs, costs of management, saving items and insurance company margin. In the Czech Republic is the written insurance defined as: ,specified insurance includes all due amounts payable during the accounting period in accordance with insurance agreements independently of the fact if these amounts are related to the later accounting periods“. Written premium includes premium from new insurance agreements, from renewed insurance agreements, changes of existing agreements and received reinsurance premium. Specified premium represents a profit for the insurance company and simultaneously appears a receivable account behind the client (Bokšová, 2010). Receivable from gross written premium does not arise from legal insurance and life unit link. In these cases is account on the cash basis (Fox et al, 2013).

Often discussed question is whether account about the premium in a set year in accordance with its maturity or account about the year's premium without the connection to particular payments. I think that written premium originates without a connection to particular payments because the payments themselves are not a specification but only a way of payment.

Even for insurance companies is valid that profits and costs must be declared at the moment of their occurrence and in a period they are objectively and time connected with, it means keeping the 
accrual principle of accounting. Part of the specified premium that is in the insurance company payable in the current year is related to following accounting periods must be time distinguished with help of the technical reserve for unearned premium, separately for life and non-life insurance, i.e. on the technical account of the non-life insurance or to the technical account of the life insurance. Technical insurance reserves are created into cost and are payable into insurance company profits. Direction of EU make possible to use several methods for the calculation of unearned premium reserve (method with linear risk distribution - pro rata temporis, twenty-fourth, twelfth or methods with non-linear risk distribution).

There are several moments for which the insurance policy premium might be recognised as revenue. These include:

- when the insurance contract is signed;

- when the insurance policy becomes effective;

- when the premium is received;

- when the premium is due from the policyholder.

Obviously premium revenue for life insurance is recognised as an income when the premium is received. In contrary for property-casualty insurance the premium revenue is obviously recognised over time as the risk covered by the policy runs off (concept of "deferral-matching approach" with use of "Written Premiums" account).

Based on IFRS 4 Insurance Contracts treatment there is expected an asset-liability approach rather than a deferral-matching approach. Based on such asset-liability approach, revenue shall be recognised once the insurance company gained a control over the asset resulting from the revenue. Within the moment the insurance policy becomes effective there is recognised the total amount of premium charged, that's why there wouldn't be recognised any unearned premium revenue (Albu $e t$ al., 2013; Bokšová, 2010; Strouhal et al., 2014).

However, it shall be stated, that such approach surely not utilise the concept of earned premium. For this reason profit/loss statement relying on earned premium should need to be adapted to reflect the different premium revenue recognition treatment. Policy year concept from this perfective could better reflect the premium reporting approach rather than fiscal (accounting) year (Jáčová and Horák, 2013; Strouhal et al., 2014).

\section{RESEARCH METHODOLOGY}

Based on IAS 18 revenue is considered as an income arising in the course of ordinary activities of an entity and is referred to by a variety of different names, e.g. sales or fees. Revenue is measured at fair value of the consideration received or receivable.

As a research tool structured personal interview with Mr Pavel Mencl who acts as group internal auditor at Generali PPF Holding B.V. Questions were also forwarded to European companies being part of Generali PPF Holding B.V. The object of this research was to compare the reporting of gross written premium in selected countries of Central and Eastern Europe by Generali PPF Holding branches. Firstly it was necessary to define a set of questions which were addressed to insurance companies in particular countries:

- If there are contracts in non-life insurance with less than annual instalments (quarterly, monthly), does the gross written premium for the year contain only the instalments that are due in this year or the whole contacted amount? 
- If there are contracts with life insurance, is the gross written premium counted on paid premiums during the year or a different method is used?

- If there are contracts with several instalments in the year, how big is the receivable for the client? i.e. Is the receivable created in the amount of the instalment or the amount counted on an annual base?

- If there are taxes connected to the premium, are these taxes part of the gross written premium and then deducted as cost, or are they accounted separately?

The main aim of this set of question was to find whether the gross written premium is reported in all selected countries in the same way and how many of these countries are in favour of the procedures used in the Czech Republic. The authors of the research believe that the methodology of reporting of the written premium in the Czech Republic is not representing true picture of reality during the year, as the gross written premium in most of the insurance companies in the Czech Republic is charged under the payment method set in the contract (annually, quarterly, monthly, etc.), but revenues for the accounting period from gross written premium are always shown in the proper amount. However the biggest problem is that majority of insurance companies belong to larger groups and therefore at least for the purposes of consolidation it is necessary to work with comparable data.

\section{RESULTS}

Responses were collected in scope of the survey from 13 countries, including the Czech Republic. Based on the analysis it was found that there is not unified methodology of reporting of gross written premium in these countries even within one single insurance group. From the authors' perspective the option A, i.e. charging of the gross written premium on the basis of annual premium, is the most proper presentation.

\subsection{Non-Life Gross Written Premium}

There are currently following options for non-life insurance:

- Option A - Gross written premium is charged on the basis of annual premium.

- Bulgaria, Croatia, Poland, Romania and Ukraine.

- Option B - Gross written premium is charged on the basis of instalments (set method of payment).

○ Czech Republic, Hungary, Serbia, Slovakia and Slovenia.

- Option $\mathrm{C}-$ Gross written premium is charged at the time of acceptance of the cash payment.

- Belarus and Kazakhstan. There is a high probability of failure to pay the claim from the insurance contract in these states, and therefore the revenues are showed at the moment when the payment is credited.

- Option D - Gross written premium is charged at one time for the entire contract.

- Russia, and also within certain Anglo-Saxon countries.

\subsection{Life Classic Gross Written Premium}

There are currently following options for the life classic insurance:

- Option A - Gross written premium is charged on the basis of annual premium.

○ Bulgaria, Romania

- Option B - Gross written premium is charged on the basis of instalments (set method of payment).

○ Czech Republic, Hungary, Poland, Russia, Slovakia, Slovenia and Ukraine. 
- Option C - Gross written premium is charged at the time of acceptance of the cash payment.

- Kazakhstan and Serbia.

- Option D - Gross written premium is charged at one time for the entire contract.

o nowhere

\subsection{Life Unit Linked Gross Written Premium}

There are currently following options for life unit linked insurance:

- Option A - Gross written premium is charged on the basis of annual premium.

- Bulgaria

- Option B - Gross written premium is charged on the basis of instalments (set method of payment).

- Poland and Romania.

- Option C - Gross written premium is charged at the time of acceptance of the cash payment.

○ Croatia, Czech Republic, Hungary, Slovakia and Slovenia.

- Option D - Gross written premium is charged at one time for the entire contract.

$\circ$ nowhere

The following table illustratively summarizes the various options of reporting of gross written premium in particular countries (despite by companies forming one insurance group), divided into non-life insurance, life classic insurance and life unit linked insurance.

\section{Table 1 Recognition of Gross Written Premium in Selected CEE Countries}

\begin{tabular}{llll} 
Country & \multicolumn{2}{l}{ type of insurance } & \\
& Non-life & Life classic & $\begin{array}{l}\text { Life unit } \\
\text { linked }\end{array}$ \\
Belarus & C & N/A & N/A \\
Bulgaria & A & A & A \\
Croatia & A & C & C \\
Czech & B & B & C \\
Hungary & B & B & C \\
Kazakhstan & C & C & N/A \\
Poland & A & B & B \\
Romania & A & A & B \\
Russia & D & B & N/A \\
Serbia & B & C & N/A \\
Slovakia & B & B & C \\
Slovenia & B & B & C \\
Ukraine & A & B & N/A
\end{tabular}

(Source: results are based on structured interview with Mr Mencl (Group Internal Auditor for CEE Region - Generalli PPF Holding B.V.) and the data provided by the Group)

Notes:

A (annual) - accounting for gross written premium at once based on contractual amount (annual amount)

B (instalments) - accounting for gross written premium based on instalment frequency

C (cash) - accounting for gross written premium based on collection of gross written premium

$\mathrm{D}$ (contract) - gross written premium is charged on the basis of the entire contract

\section{CONCLUSION}


This analysis confirmed that the presented information about the revenues of commercial insurance companies (in terms of gross written premium) in particular countries is based on different principles and recognition methodologies. From this perspective statistical information provided from each region (Central Europe, Eastern bloc, etc.), types of insurance (non-life, life classic, life unit linked) and the like are biased and in many cases they cannot be aggregated. Even companies forming one insurance group (within our specific case Generali PPF Holding B.V.) report revenues from gross written premium in different ways (yearly based without distinction of accruals and deferrals, quarterly based etc.) - from this perspective it seems we are trying to summarize what's called at grammar school "apples with pears" and the results are not only comparable but for this perspective even not reliable for making proper economic decisions.

For comparability of data and its information capability it is necessary to establish a precise definition of gross written premium. Only in such case there would be possible to ensure the credibility of statistical information. However even the current updating project of standard IFRS 4 is not dealing with this topic what might be considered as a major limitation not only of our analysis but also of current stage of reporting of gross-written premiums worldwide. Paradoxically even new IFRS 15 standard also do not deal with this issue.

To generalize our findings it shall be stated that currently presented data about gross written premiums in worldwide statistical books are implausible figures and have to be omitted as a possible data source for making any economic decisions.

\section{REFERENCES}

Albu, C. N., et al. (2013) Implementation of IFRS for SMEs in Emerging Economies: Stakeholders Perceptions in the Czech Republic, Hungary, Romania and Turkey, Journal of International Financial Management and Accounting, vol. 24, no. 2, pp. 140-175.

Belás, J., Cipovová, E., Novák, P., \& Polách, J. (2012) Dopady použitia základného prístupu interných ratingov na finančnú výkonnost banky, E+M Ekonomie a Management, vol. 2012, no. 3, pp. 142-155.

Bokšová, J. (2010) Účetnictví komerčních pojištoven - specifika v ČR. Prague: Wolters Kluwer.

Bonaci, C., Matis, D., \& Strouhal, J. (2010) Crisis of Fair Value Measurement? Some Defense of the Best of All Bad Measurement Bases, WSEAS Transactions on Business and Economics, vol. 7, no. 2, pp. 114-125.

Fox, A., Hannah, G., Helliar, C., \& Veneziani, M. (2013) The Costs and Benefits of IFRS Implementation in the UK and Italy, Journal of Applied Accounting Research, vol. 14, no. 1, pp. 86-101.

Jáčová, H., \& Horák, J. (2013) Application of Strategic Management in Enterprises Located in the Czech Republic as a Tool of Resources Management Support, WIT Transactions on Ecology and the Environment, no. 179, pp. 767-777.

Smrčka, L., Arltová, M., \& Schönfeld, J. (2013) "Příčiny neúspěšného prosazování sanačních postupů v insolvenční realitě”, Politická ekonomie, vol. 61, no. 2. 188-208

Strouhal, J., Židlická, R., \& Cardová, Z. (2014) Účetnictví - velká kniha př́kladů. Brno: Albatros Media. 